\title{
Tumor-Based Genetic Testing and Familial Cancer Risk
}

\author{
Andrea Forman ${ }^{1}$ and Jilliane Sotelo ${ }^{2}$ \\ ${ }^{1}$ Department of Clinical Genetics, Risk Assessment Program, Fox Chase Cancer Center, Philadelphia, \\ Pennsylvania 19111, USA \\ ${ }^{2}$ Center for Cancer Genetics and Prevention, Dana Farber Cancer Institute, Boston, Massachusetts 02215, USA \\ Correspondence: AFormanCGC@gmail.com
}

\begin{abstract}
As genetic testing on somatic tumor tissue becomes a more routine part of personalized cancer treatment, a growing opportunity arises to identify hereditary germline variants within those results. These germline results can affect future cancer screening for both patients and their family members. Finding this germline information can be complicated as a result of differences between somatic and germline testing processes, nomenclature, and outcome goals (e.g., treatment impact). The goal of this review is to highlight differences between somatic and germline testing and outline a potential guide to allow for appropriate clinical interpretation of somatic testing results in order to better facilitate genetic counseling referrals and confirmatory germline testing.
\end{abstract}

Timentions umor characteristics have long guided cancer treatment and follow-up care. As awareness of hereditary cancer risk has grown, correlations between histopathologic tumor features and prevalence of germline cancer risk variants have also been noted. Triple-negative breast cancers are more likely to carry BRCA1 variants compared to estrogen-positive tumors (Peshkin et al. 2010; Krammer et al. 2017). Specific renal cancer histology may suggest particular hereditary renal cancer risk genes, such as oncocytic chromophobe tumors associated with variants in the FLCN gene (Peng and Chen 2018). Markers of mismatch repair deficiency were found to include microsatellite instability and loss of expression of certain proteins on immunohistochemistry (IHC), leading to recommendations for universal screening protocols for colon and endometrial tumors to screen for Lynch syndrome (de la Chapelle and Hampel 2010).

Recent technologies allow for genomic sequencing of tumor tissue with an increased understanding of the tumor genome and its impact on personalized cancer treatment. A growing number of therapies can target certain somatic variants, and tumor genetic testing is becoming a more integral part of cancer treatment. As this testing becomes more widely used, clinicians must be familiar with the potential for somatic tumor testing to identify hereditary cancer risks and recognize the need to facilitate confirmatory testing through genetic counseling. Knowledge of hereditary cancer risk can help patients determine future screening and provide family

Editors: Laura Hercher, Barbara Biesecker, and Jehannine C. Austin

Additional Perspectives on Genetic Counseling: Clinical Practice and Ethical Considerations available at

www.perspectivesinmedicine.org

Copyright (C) 2020 Cold Spring Harbor Laboratory Press; all rights reserved; doi: 10.1101/cshperspect.a036590

Cite this article as Cold Spring Harb Perspect Med 2020;10:a036590 
A. Forman and J. Sotelo

members with valuable information (Jain et al. 2016).

\section{THE MISMATCH REPAIR PATHWAY AND LYNCH SYNDROME}

Detection of hereditary cancer risk often begins with a family history-based assessment and various criteria assist in determining personal and family history most likely to yield informative genetic testing results. However, such criteria can miss at-risk families. For example, in Lynch syndrome, also called hereditary nonpolyposis colorectal cancer syndrome (HNPCC), family history-based guidelines may miss up to $39 \%$ of at-risk families (Syngal et al. 2000). Pathogenic variants in these genes $(M L H 1, M S H 2, M S H 6$, PMS2, and EPCAM) cause mismatch repair deficiency (MMRD) and lead to distinctive tumor characteristics including microsatellite instability (MSI) and IHC-detected loss of protein expression from the relevant genes (de la Chapelle and Hampel 2010), which provide tumor-based avenues to identify at-risk patients, including those missed by family history.

\section{Microsatellite Instability}

Microsatellites are common regions of chromosomal DNA with repeating sequences of DNA nucleotides. These repeat sequences can expand in the setting of MMRD, such as those caused by Lynch syndrome, and present with high levels of MSI. Approximately $20 \%$ of uterine cancers will be MSI-high, with $<10 \%$ of those associated with a diagnosis of Lynch syndrome (Hampel et al. 2006). Approximately $15 \%$ of colorectal tumors will show high MSI, with about one-third of those having Lynch syndrome (de la Chapelle and Hampel 2010). Not all MSI-high tumors will have Lynch syndrome as other events, particularly somatic hypermethylation of the MLH1 promoter region and biallelic somatic inactivation of one of the genes associated with Lynch syndrome, can also lead to MSI-high findings (Salvador et al. 2019).

MSI testing has historically been a polymerase chain reaction (PCR)-based panel focusing on five loci identified by the National Cancer
Institute (Boland et al. 1998). Variations have been implemented in many pathology departments as universal screening protocols have become more prevalent. As next-generation sequencing (NGS) technologies have expanded in both the tumor and germline genetic testing setting, the ability to detect microsatellite repeats using NGS methodology has been confirmed to have comparable sensitivity and specificity, allowing this information to be incorporated into some tumor sequencing test reports (Salipante et al. 2014).

\section{Immunohistochemistry}

Protein expression testing by IHC is also a highly sensitive screening tool for Lynch syndrome. Cancers that develop because of inactivation of the MMR genes typically show a complete lack of protein expression for those genes within the tumor (de la Chapelle and Hampel 2010). In Lynch syndrome, the patient inherits a single pathogenic variant on one of two alleles inherited from the parents. As part of the tumorigenesis process, the wild-type allele will characteristically become nonfunctional (through an acquired somatic variant or loss of heterozygosity) leading to a lack of protein expression in tumor tissue, whereas normal tissue will retain detectable protein levels because of one functional wild-type allele. Abnormal IHC results can also be acquired, similar to high microsatellite instability, through acquired biallelic somatic variants and hypermethylation of the MLH1 promoter region (Salvador et al. 2019).

IHC is often the preferred method of routine Lynch screening as it is convenient, inexpensive, and makes use of supplies and expertise readily available in most pathology departments. Also, unlike MSI, IHC allows for more specificity in identifying the MMR gene likely affected. MMR proteins act as heterodimers, with MLH1 proteins typically pairing with PMS2 and MSH2 working with MSH6 (Boland et al. 2008). Nonfunctioning $\mathrm{MLH1}$ genes (whether through promoter hypermethylation, biallelic somatic variants, or germline $M L H 1$ variants) will typically lead to loss of both MLH1 and PMS2 protein expression within tumor cells. Inactivation 
Tumor-Based Genetic Testing

Table 1. Simplified summary of tumor microsatellite instability (MSI) and immunohistochemistry (IHC) assessment for Lynch Syndrome (LS)

\begin{tabular}{|c|c|c|c|c|c|}
\hline \multicolumn{4}{|c|}{$\mathrm{IHC}$} & \multirow[b]{2}{*}{ MSI } & \multirow[b]{2}{*}{ Possible explanation } \\
\hline MLH1 & $\mathrm{MSH} 2$ & MSH6 & PMS2 & & \\
\hline+ & + & + & + & MSS or low & $\begin{array}{l}\text { Sporadic cancer } \\
\text { Possibly non-Lynch syndrome cancer syndrome }\end{array}$ \\
\hline $\mathrm{N} / \mathrm{a}$ & $\mathrm{N} / \mathrm{a}$ & $\mathrm{N} / \mathrm{a}$ & $\mathrm{N} / \mathrm{a}$ & High & $\begin{array}{l}\text { Germline mutation in any LS gene } \\
\text { Sporadic cancer (MPH, DSM, or other etiology) }\end{array}$ \\
\hline- & + & + & - & $\mathrm{N} / \mathrm{a}$ & $\begin{array}{l}\text { Germline mutation-typically } M L H 1 \text {, rarely } P M S 2 \\
B R A F \text { mutation (colon tumor only) or } \mathrm{MPH} \\
\text { DSM in } M L H 1 \text { and/or } P M S 2\end{array}$ \\
\hline+ & - & - & + & $\mathrm{N} / \mathrm{a}$ & $\begin{array}{l}\text { Germline mutation-typically } M S H 2 / E P C A M \text {, rarely } M S H 6 \\
\text { DSM in } M S H 2 \text { and/or } M S H 6\end{array}$ \\
\hline+ & + & + & - & $\mathrm{N} / \mathrm{a}$ & $\begin{array}{l}\text { Germline mutation in } P M S 2 \text {, rarely in } M L H 1 \\
\text { DSM in } P M S 2 \text { or (rarely) } M L H 1\end{array}$ \\
\hline+ & + & - & + & $\mathrm{N} / \mathrm{a}$ & $\begin{array}{l}\text { Germline mutation in } M S H 6 \text {, rarely in } M S H 2 \\
\text { DSM in } M S H 6 \text { or (rarely) } M S H 2\end{array}$ \\
\hline
\end{tabular}

(MPH) MLH1 promoter hypermethylation, (DSMs) double somatic mutations.

of only the PMS2 gene will often allow expression of the MLH1 protein and PMS2 protein expression alone absent on IHC. Similarly, MSH2 inactivation will lead to loss of both MSH2 and MSH6 protein expression, whereas inactivation of MSH6 will only affect MSH6 protein expression. It is important to note that MSH6 protein expression can be decreased compared to pretreatment levels in tissue that has undergone chemoradiation (Goldstein et al. 2017), leading to a false report of absence of MSH6 protein in a biopsy or resection of the treated tissue. The National Comprehensive Cancer Network has summarized common explanations for loss of IHC and follow-up recommendations based on IHC and MSI results, a modified form of which is available in Table 1 (NCCN 1.2018).

\section{Universal MMR Screening}

Routine screening of colorectal and endometrial tumors for microsatellite stability and IHC has been shown to increase detection of Lynch syndrome beyond family history-based guidelines and has been encouraged as part of routine care in the treatment of colorectal and uterine cancer (Hampel et al. 2008; EGAPP 2009). Universal screening, and subsequent identification of Lynch syndrome, also allows for "cascade testing" for family members unaffected by cancer, increasing cost-effectiveness of such testing and providing health benefits to extended relatives (Hampel 2016). MMRD also has a growing impact on cancer treatment with the recent discovery of beneficial immunotherapies in MMRD tumors of various types (Le et al. 2015), supporting the need for even broader MMRD screening.

As both tumor gene sequencing and identification of MMRD have a growing impact on cancer treatment, it has been posited that upfront tumor sequencing may effectively replace screening programs focusing only on IHC and/ or MSI testing. Identifying Lynch syndrome through IHC/MSI screening programs can require multiple steps over an extended period of time (i.e., tumor screening, $B R A F$ testing, $M L H 1$ hypermethylation testing, and finally germline testing). A recent study found that test sensitivity improved with up-front tumor testing and allowed for identification of additional treatment-related information, such as KRAS status and tumor mutational burden, compiled within one test (Hampel et al. 2018). Feasibility and cost-effectiveness of this method compared to in-house IHC/MSI testing has yet to be determined. 
A. Forman and J. Sotelo

\section{TUMOR SEQUENCING ANALYSIS AND IMPLICATIONS FOR GERMLINE ALTERATION DETECTION}

Somatic gene sequencing analyses are most frequently performed by NGS or massively parallel sequencing. This technology replaced singletarget detection assays (e.g., Sanger sequencing) with simultaneous evaluation of many genes, utilizing millions of short nucleic acids sequencing in parallel (Bentley et al. 2008; Shendure and Ji 2008). However, the application of this technology has been inconsistent. In a 2015 survey by a clinical laboratory-focused working group from the Association for Molecular Pathology, responders reported using NGS testing in panels ranging from 1 to 10 genes to $>100$. A small number of laboratories reported performing exome (12\%) or genome (5\%) analysis. Although all participants reported small-nucleotide variants (SNVs), or the change of a single nucleotide, there was considerably more variability in reporting of copy number variants (CNVs). Only 35\%-37\% of participating laboratories analyzed for CNVs (Li et al. 2017).

\section{METHODS OF ANALYSIS (TUMOR GENE SEQUENCING)}

Analysis is typically carried out using ampliconbased methods, either through vendor-created tools with varying levels of customization or through targeted enrichment with hybridization capture (Cheng et al. 2015). Amplicon methods use PCR to select for desired sequences by using primers that target a particular gene or stretch of DNA. This process creates short segments of DNA for analysis, called amplicons. Amplicon-based methods without hybridization capture are typically more affordable and require less clinical laboratory investment. They are convenient, particularly for smaller gene panels, but susceptible to artifacts of random sequence mismatch and uneven sequence coverage across areas of interest (Nikiforova et al. 2013; Singh et al. 2013; Lin et al. 2014; Luthra et al. 2014; Tsongalis et al. 2014). Additional challenges arise as certain variants may not be detected due to poor coverage in an amplicon-based sys- tem or not reported because of quality control methods.

Some analyses use hybridization capture. For these assays, amplicon-based NGS is performed, and then biotinylated probes are used to specifically bind to areas of interest within the desired sequences. These areas may be known sequences with typically poor coverage, areas with pseudogene homology, or any other stretch of DNA for which additional amplicons for analysis may be desired. Once, the probes are bound and pulled down, one is left with a more specific library of sequences of interest. This methodology can create more even sequence coverage and reduce the amount of mismatch artifact. For these reasons, large panels have better performance when utilizing a hybridization capture tool with which more accurate estimates of CNVs can be made. However, this frequently involves significant infrastructure and bioinformatics investment (Cheng et al. 2015). The additive value of this investment may not be viewed as important in the treatment setting based on the goals of the institution and the analysis.

Deletion and duplication analysis using an NGS platform can be challenging. Probes must be selected appropriately to allow for even coverage and reduction of pseudogene homology, which is sometimes very challenging. The ability to detect a single exon deletion is quite good with higher levels of sequencing in the flanking intronic regions. However, most NGS assays used for somatic sequencing focus on exonic regions only. Depending on the bioinformatic tool used, deletions of up to 25 base pairs are easy to analyze provided the whole surrounding area has been sequenced. However, larger insertions and deletions can lead to errors in mapping because the aligner tool, the bioinformatics tool that matches the reported sequence to the expected sequence, must contend with large extra or missing portions of DNA when comparing the two sequences. This can lead to lack of alignment or misalignment of the sequence and therefore a possible missed variant call (Cheng et al. 2015, 2017). Understanding which methodology was used for testing is an important distinction when considering the 
ability of a somatic analysis to identify a germline variant.

\section{GERMLINE IMPLICATIONS FROM SOMATIC TESTING}

For the clinical genetic counselor or other health-care provider, a primary concern when considering a somatic gene report is whether there are germline implications. The IMPACT program at Memorial Sloan Kettering, which offers paired somatic and germline analysis to participants, found $\sim 15 \%$ of unselected individuals harbor a pathogenic germline variant. Discordance between tumor type and cancer susceptibility gene were identified in $60 \%$ of individuals, and about one-fourth had loss of the second allele (Schrader et al. 2016), suggesting that paired analysis may be a tool for opportunistic hereditary cancer screening in cancer patients who might not otherwise be identified through personal and family history assessment.

However, most cancer patients in the United States do not receive paired analysis when undergoing somatic testing. Using a somatic report as a screening tool for germline alterations can be complicated. Utilization is made even more overwhelming when considering that the mutational burden of these tumors can be high; more than 100 sequencing alterations and CNVs can be identified within a single sample. Studies have suggested that $20 \%$ of patients with ovarian cancer have a somatic gene variant associated with the Fanconi anemia/DNA repair pathway (Kanchi et al. 2014), and TP53 variants were identified in $>40 \%$ of all tumors analyzed in multiple organs (Zehir et al. 2017). Considering that the recent American Society of Clinical Oncology (ASCO) guidelines recommend genetic testing for all somatic BRCA1 and BRCA2 carriers, the ability to parse out germline alterations is both important and timely.

\section{SOMATIC ANALYSIS COMPARED TO GERMLINE}

When looking at a somatic report for germline implications, it is important to identify a few key items: intentional germline filtering, transcript utilization, tumor heterogeneity and purity, allelic fraction, possible founder variants, genes atypical to the tumorigenesis process in the organ, and tumor mutational burden. Differences in the variant classification process between germline and somatic variants should also be kept in mind.

\section{Filtration}

In some cases, tumor analysis intentionally filters out germline variants. Previously, there have been instances in which laboratories felt that patients were not adequately consented to receive incidental germline findings and therefore excluded these variants from the analysis (Mandelker and Zhang 2018). Other laboratories intentionally filter out suspected or known germline variants so that they can report on pure somatic alterations, thought to be most active in the tumor and therefore the best targets for therapy (Raymond et al. 2016; Mandelker and Zhang 2018). Therefore, it is possible that a known pathogenic germline variant may not appear on the somatic report if not thought to be clinically significant for the treatment of the cancer.

\section{Transcript Use}

Joint Commission Guidelines recommend that the canonical transcript (determined by consensus, longest coding sequence [CDS] or longest cDNA as listed in Ensembl [Zerbino et al. 2018] and University of California, Southern California (UCSC) Genome Browser [Kent et al. 2002]) be used for somatic as well as germline analysis (Li et al. 2017). However, because of the large number of aberrations in the somatic gene setting, there may be discrepancies between nucleotide and amino acid nomenclature when compared to HGVS nomenclature for that transcript at that location (Dalgleish et al. 2010). For example, a recent somatic report found a MUTYH pathogenic variant called c.1138delC (p.A382fs) at an allele frequency of $57 \%$. The variant was confirmed to be present in the germline, but the nomenclature was different, c.1147del (p.Ala385Profs*23). Many publicly 
available databases, such as ClinVar (Landrum et al. 2018), will list aliases, and alternate locations may be included as a known alias. However, if discrepancy continues to exist, it may be beneficial to request genomic coordinates for comparison against existing databases.

In some research settings, an annotation, known as "Best Effect" annotation, may be given. This annotation considers all the transcriptional outcomes of all known transcripts at that location and reports the most deleterious (McLaren et al. 2016). As an example, if 15 known transcripts were identified for a single gene, and these were anticipated to result in 10 different transcriptional outcomes including intronic, missense, and splice site variants, the Best Effect annotation would report the splice site alteration because that would most affect translation. As the canonical transcript is sometimes chosen arbitrarily, and different transcripts of the same gene are transcribed in different organs, it is not currently clear which transcript is active at any given time in the tumor, so reporting the most severe effect may be desirable (Barrera et al. 2008; Singer et al. 2008; Wang et al. 2008; Gupta et al. 2010). The Best Effect annotation will frequently not match listed alterations in germline databases and genomic coordinates should be retrieved from the testing laboratory.

\section{Tumor Heterogeneity}

Human cancer cells in a given tumor are known to display differences in cellular morphology, metabolism, motility, proliferation, and metastatic potential (Fidler and Hart 1982; Heppner 1984; Nicolson 1984; Dick 2008). This extends to gene alteration and expression. Each tumor is a small universe controlled with Darwinian evolution of tumorigenesis, in which a high level of cell divisions creates a perfect environment for multiple mutants, potentially acting in response to a variety of intratumor and extraorganism pressures. As the analyzed tumor in most cases represents just a small locus of this universe, the analysis may not capture the germline alteration, either because of loss through CNVs or reversion, and therefore the germline alteration does not appear on the report (Cheng et al. 2015; Cortes-Ciriano et al. 2017; Bailey et al. 2018; Knijnenburg et al. 2018).

\section{Allelic Fraction}

Allelic fraction, or the percent of the reads identifying the given alteration, has been posited as a method for determination of possible germline result. However, allelic fraction can be biased by multiple factors (Cheng et al. 2017; Knijnenburg et al. 2018). Indel alterations have an allelic fraction that frequently falls outside of anticipated $40 \%-60 \%$ ranges for germline variants (Cheng et al. 2017). If the given sample for analysis has a high level of tumor content, the allelic fraction may be biased by the heterogeneity of the sample itself. If the tumor purity has been compromised and the sample contains a high level of normal cells, the allelic fraction may also be impacted (Bailey et al. 2018). Homopolymer repeat regions may falsely elevate the amount of reads at any given location, therefore causing an imbalance of allelic fraction between the alteration and wild type (Cheng et al. 2017). Additionally, if a sample contains a high level of CNVs, allelic dropout in some cells of either the wild-type allele or altered allele could lead to a misleading allelic fraction that varies widely from the anticipated 50\% (Knijnenburg et al. 2018; Sun et al. 2018). Last, reversion is a well-documented phenomenon, and loss of the mutant allele in samples from previously treated disease may mask an underlying germline variant (Domchek 2017; Mayor et al. 2017; Weigelt et al. 2017).

\section{Presence of Founder Variants}

The presence of a common founder variant is one of the best predictors that a somatic alteration is germline. Founder variants are welltypified in many genes including the BRCA1 and $B R C A 2$ Ashkenazi Jewish founder variants (BRCA1 c.68_69delAG and c.5266dupC, BRCA2 c.5946delT) and Eastern European variants in CHEK2 (c.1100delC). The presence of one of these founder variants in a tumor specimen supports the need for germline analysis (Knijnenburg et al. 2018). Conversely, a com- 
mon founder variant may be filtered out of a somatic testing report if the filters on the somatic analysis are such that an alteration with population frequency $>1 \%$ (typically derived from Gnomad [Karczewski et al. 2019] or ExAc [Lek et al. 2016]) are automatically filtered out (Cheng et al. 2015; Li et al. 2017).

\section{Discordant Tumor Types}

Although defining typical alterations within categories of tumors is still underway, many of the genes that increase empiric risk of cancer in certain organs are frequently involved in tumorigenesis in those same organs (Bailey et al. 2018). However, for most genes, their presence as prominent somatic alterations in discordant tumors should be a flag for possible germline involvement. For example, the presence of a BRCA2 variant in papillary thyroid cancer should be considered for germline analysis. TP53 and PTEN would be notable exceptions to this rule because of their constitutive nature and relatively common somatic association of multiple tumor types. (Bailey et al. 2018) MSKIMPACT has found that among tumor paired normal samples with clinically actionable germline alterations, discordance between tumor type and cancer susceptibility gene was identified in $60 \%$ of individuals (Cheng et al. 2017). This suggests that an alteration identified in a gene not typical to the tumorigenesis process of that organ, particularly one that would be pathogenic in the germline setting, should be considered for germline genetic analysis.

\section{Tumor Mutational Burden}

High tumor mutational burden (TMB) is another scenario in which one should consider genetic testing. Although TMB and MSI have a high level of correlation (Huang et al. 2018), they do not assess for the same somatic phenomena. TMB is the number of relative variants within tumor cells versus the "typical," and MSI refers specifically to the number of repeat expansions of microsatellites of DNA. For tumors primarily driven by the mismatch repair (MMR) genes, high TMB will be detected (Alexandrov et al.
2013; Kim et al. 2013; Cortes-Ciriano et al. 2017; Bailey et al. 2018; Knijnenburg et al. 2018). In cancers known to be associated with the Lynch spectrum (e.g., colon, gastric, uterine, ovarian, urothelial, and kidney), referral to genetics should be considered if a high level of TMB exists (Cortes-Ciriano et al. 2017; Bailey et al. 2018). It is important to note that although the germline variant may be identified in the somatic analysis, allelic frequency may be an unreliable flag because of the hypermutated nature, and allelic loss of the germline alteration may have happened if large numbers of CNVs are present (Cortes-Ciriano et al. 2017; Bailey et al. 2018).

\section{Variant Classification}

Joint Consensus Recommendations for the Standards and Guidelines in the Interpretation and Reporting of Sequence Variants is made by the Association for Molecular Pathology (AMP), American Society of Clinical Oncology (ASCO), and the College of American Pathologists (CAP). Classification based on their recommendation is based on a four-tier system (Table 2): tier I, variants with strong clinical significance; tier II, variants with potential clinical significance; tier III, variants of unknown clinical significance; and tier IV, variants deemed benign or likely benign ( $\mathrm{Li}$ et al. 2017). Unlike germline variants, in which measurable increased risk of cancer over a lifetime is an indicator of pathogenicity, somatic variants are interpreted based on their impact on clinical care. Therefore, those alterations that predict sensitivity, resistance, or toxicity to a specific therapy can be targeted as part of standard or investigational therapy (i.e., clinical trials). Those alterations that affect prognosis or diagnosis will be tiered in the highest tier. Alterations known to be pathogenic in the germline setting that do not fit the above criteria may therefore be placed in a lower tier. As an example, if a breast cancer patient were to carry a germline EGFR T790M variant, this may not be classified as a tier I alteration, as it has no bearing on the patient's breast cancer treatment. It is important to remember that the primary goal of germline 
A. Forman and J. Sotelo

Table 2. Somatic variant classification system

\begin{tabular}{|c|c|c|c|}
\hline \multirow[t]{2}{*}{ Tier I } & \multirow[t]{2}{*}{$\begin{array}{l}\text { Variants of strong } \\
\text { clinical significance }\end{array}$} & Level A evidence & $\begin{array}{l}\text { FDA-approved therapy } \\
\text { Included in professional guidelines }\end{array}$ \\
\hline & & Level B evidence & $\begin{array}{l}\text { Well-powered studies with consensus from leaders in the } \\
\text { field }\end{array}$ \\
\hline \multirow[t]{3}{*}{ Tier II } & $\begin{array}{l}\text { Variants of potential } \\
\text { clinical significance }\end{array}$ & Level C evidence & $\begin{array}{l}\text { FDA-approved therapies for different tumor types or } \\
\text { investigational therapies }\end{array}$ \\
\hline & & & Multiple small published studies with some consensus \\
\hline & & Level D evidence & Preclinical trials or a few case reports without consensus \\
\hline \multirow[t]{2}{*}{ Tier III } & $\begin{array}{l}\text { Variants of unknown } \\
\text { clinical significance }\end{array}$ & & $\begin{array}{l}\text { Not observed at a significant allele frequency in the general } \\
\text { or specific subpopulation databases, or pan-cancer or } \\
\text { tumor-specific variant databases }\end{array}$ \\
\hline & & & No convincing published evidence of cancer association \\
\hline \multirow[t]{2}{*}{ Tier IV } & $\begin{array}{l}\text { Benign or likely benign } \\
\text { variants }\end{array}$ & & $\begin{array}{l}\text { Observed at significant allele frequency in the general or } \\
\text { specific subpopulation databases }\end{array}$ \\
\hline & & & No existing published evidence of cancer association \\
\hline
\end{tabular}

annotation is to identify alterations causing measurable changes in risk at the whole-body level. Annotation in the somatic setting, however, is used to identify those alterations that create a clinically actionable change in that type of tumor in that particular organ. This classification is by necessity not static and relies on the currently available technologies, therapeutic targets, and clinical trials. Although the joint consensus recommendations do indicate that those variants at high likelihood of being germline, either because of identification in a paired normal sample or because of other features (i.e., $50 \%$ allelic fraction in alterations identified as pathogenic in germline databases, known founder variants), should be classified as tier 1, germline alterations can be hard to detect or have possible ambiguous annotation and therefore may be relegated to a lower tier (Li et al. 2017).

In contrast, guidelines for germline analysis are put forth by the American College of Medical Genetics (ACMG). They include a five-basket system that classifies an alteration as Pathogenic (P), Likely Pathogenic (LP), Variant of Uncertain Significance (VUS), Likely Benign (LB), and Benign (B). Variants are scored with two scales; one "Evidence of Benign Impact" and the other "Evidence of Pathogenicity". The lines of evidence that support pathogenicity are classified as Very Strong, Strong, Moderate, Supporting. The lines of evidence that support benign impacts are classified as Stand Alone,
Strong, and Supporting. Set combinations of this classification correlate to the variant basket and lead to the final classification (Richards et al. 2015).

\section{Case 1}

A 37-year-old man presented to the emergency room with rectal bleeding. Colonoscopy identified a $3-\mathrm{cm}$ mass in the cecum. Adenocarcinoma is confirmed by biopsy. He underwent a right hemicolectomy. Immunohistochemistry was performed with all four proteins (MLH1, MSH2, MSH6 and PMS2) present and MSI detected at 0:10 markers. On somatic analysis, the tumor showed a high level of TMB. The specimen was $60 \%$ tumor. Two MSH6 tier III variants were detected: c.3938_3939insTCAAAAGG GACATAGAAAA (p.A1320Sfs*5) in 6\% of reads and c. $1309 \mathrm{C}>\mathrm{G}$ (p.H437D) in 5\% of reads. Germline large gene panel analysis was performed, and the patient was found to carry the MSH6 p.A1320Sfs* 5 pathogenic variant.

This case illustrates the sometimes-increased sensitivity of somatic analysis. The particular variant identified is a well-known, pathogenic, truncating variant that causes loss of 41 terminal amino acids, leading to a nonfunctioning protein that can escape nonsense mediated decay. Therefore, a false negative was identified on IHC. An important note is that the allelic fraction in this sample was low, likely 
driven down by the overall hypermutability of this tumor. These identified somatic alterations were classified as tier III variants based on the low allelic frequency and lack of actionability in regard to treatment (immunotherapy was not available at the time of this diagnosis).

Germline genetic testing would have been indicated for this patient based on age at diagnosis. Additionally, high TMB in absence of loss of IHC could indicate a polymerase gene variant (i.e., POLE, POLD1), and these genes were included when the patient's germline testing was ordered.

\section{CLONAL HEMATOPOEISIS OF INDETERMINATE POTENTIAL (CHIP)}

The advent of NGS technologies brought an increased sensitivity to detecting genetic variants in blood cells at low allele frequencies. Sanger sequencing can detect mosaic alleles at a $15 \%$ $20 \%$ allele frequency (Rohlin et al. 2009), whereas NGS can detect low-level mosaicism down to a $2 \%$ allele frequency or lower ( $\mathrm{Li}$ and Stoneking 2012). Variants found at low allele frequencies can suggest the presence of mosaicism acquired during embryogenesis or clonal hematopoiesis (CH) (i.e., the expansions of cells with somatic variants) (Steensma et al. 2015). Clonal hematopoiesis of indeterminate potential (CHIP) generally refers to $\mathrm{CH}$ that involves driver mutations associated with myelodysplastic syndromes, such as DNMT3A, ASXL1, or TET2 (Steensma 2018). Patients with CHIP have an increased risk of progressing to a heme malignancy, of $\sim 0.5 \%-1 \%$ per year (Sperling et al. 2017), and CHIP has also been associated with acute cardiovascular events (Jaiswal et al. 2017). CHIP may also be a risk factor in the setting of bone marrow transplant as there have been cases of donor cell leukemia's arising from CHIP (Gondek et al. 2016), but other studies have suggested CHIP has no impact on overall survival of donor recipients (Frick et al. 2019). CH can be found in $>10 \%$ of the population over age 65 (Jaiswal et al. 2014), representing significant implications for clinicians interpreting germline genetic testing results. How to follow patients with age-related $\mathrm{CH}$ or $\mathrm{CHIP}$, given the poten- tial impact on risks for cardiovascular events and heme malignancies, has not been determined.

\section{CELL-FREE TUMOR DNA (ctDNA)}

Cell-free DNA (cfDNA) is free-floating DNA in many different body fluids including plasma, saliva, lymph, breast milk, bile, urine, and spinal fluid (Thierry et al. 2016; Wan et al. 2017). Cellfree tumor DNA (ctDNA) refers specifically to short pieces of DNA derived from a tumor and appears in these fluids. ctDNA develops from either cellular breakdown, apoptosis and necrosis, or through active release mechanisms, encapsulated in vesicles, or associated with protein complexes (Jahr et al. 2001; Rykova et al. 2012). Although cfDNA is common even in healthy people, patients with cancer have higher blood levels of cfDNA (Leon et al. 1977; Stroun et al. 1987; Schwarzenbach et al. 2011). The average proportion of mutated DNA in plasma is very low, $0.4 \%$ in even advanced cancers (Barbany et al. 2019). Analysis of ctDNA is known as liquid biopsy. Liquid biopsy is performed using NGS to capture tumor-specific genetic variants. Data suggests that the length of ctDNA is shorter than naturally occurring cfDNA, so liquid biopsy utilizes size selection for shorter DNA fragment lengths to increase sensitivity of the analysis (Jiang et al. 2015; Underhill et al. 2016; Hellwig et al. 2018). Ideally, these represent a better summary of the heterogeneity of the genomic landscape of a patient's tumor than perhaps a localized biopsy would. This technology could also increase early stage detection and provide genetic information about a tumor in a hard to biopsy location (Hiemcke-Jiwa et al. 2018; Zill et al. 2018).

A large-scale study in 21,807 patients with advanced cancers in more than 50 cancer types utilized a panel of 70 defined cancer genes to determine the percentage of alterations in these patients. Somatic alterations were identified in $85 \%$ of the patients overall, with a range of $51 \%$ to $93 \%$ represented across various tumor types (Zill et al. 2018). The posited applications of ctDNA include identification of disease progression (i.e., ductal carcinoma in situ to invasive ductal breast cancer), cancer screening in 
high-risk populations (i.e., prostate cancer in men over 70), and distinguishing benign from malignant disease (Barbany et al. 2019). In addition to single-gene variants, it is possible that large CNVs or chromosomal disorders may be identified (Barbany et al. 2019). Additionally, there are a number of clinical trials using liquid biopsy in known variant carriers to detect early onset of tumors (Barbany et al. 2019).

\section{IDENTIFYING GERMLINE VARIANTS THROUGH SOMATIC ANALYSIS}

It is important to emphasize that there are no consensus recommendations for assessing which somatic variants should be confirmed with germline hereditary cancer testing other than recent National Comprehensive Cancer Network (NCCN) guidelines that recommend testing for all somatic pathogenic variants found in BRCA1 or BRCA2 (NCCN 3.2019). Insurance coverage for germline confirmatory testing varies. Recommendations for such testing are likely to evolve significantly as our understanding of this testing and technologies evolve. However, here we hope to begin the development of a framework for assessment based on the information previously reviewed (see Fig. 1).

Step 1. Assess all cases for clinical testing criteria for hereditary cancer risk based on personal and family history. Given the potential for germline variants to be lost in somatic tumor testing, even cases with no suggestive somatic variants should be offered germline testing based on appropriate clinical indications.

Step 2. Determine if tumor testing shows high TMB or MSI-high features (and BRAF-negative if colorectal tumor). These features are highly suggestive of variants in the genes associated with Lynch syndrome (MLH1, MSH2, MSH6, PMS2, and EPCAM) as well as $P O L E$ and $P O L D 1$, and subsequent germline testing should be done that includes these genes, at a minimum. Although these genes are typically included in somatic testing, the genes involve difficult to sequence regions, such as the pseudogene region of PMS2, which may be excluded from somatic analysis.
Step 3. Ensure that the somatic tumor result has not filtered out germline findings. If so, any decision to proceed with germline testing will be based solely on personal and family history guidelines or other germline-variant prediction models.

Step 4. Review somatic results for common founder variants. These are highly likely to be confirmed in the germline. Examples include the three common variants in the $B R C A 1$ and BRCA2 genes associated with Jewish ancestry. It is less clear if testing is appropriate for moderate penetrance founder variants, although many of them impact cancer screening recommendations. These could include monoallelic variants in $M U T Y H$ (c.Y179C and c.G396D), APC c.I1307K, NBN c.657del5, and CHEK2 c.1100delc.

Step 5. At this point, the reviewer may be left with several variants in genes known to be associated with hereditary cancer risk and can begin the process of separating variants using the five-basket system: Benign (B), Likely Benign (LB), of Uncertain Significance (VUS), Pathogenic (P), and Likely Pathogenic (LP). Some variants will simply be noted as "detected" or similar, and further investigation may be necessary (Table 3). Variants confirmed to be B, LB, or VUS in the germline setting will generally not need germline testing unless other clinical indications are met.

Step 6. Some genes have a higher likelihood of being confirmed in the germline than others. NCCN now recommends confirmatory germline testing for all pathogenic and likely pathogenic variants in the BRCA1 and BRCA2 genes (NCCN 3.2019). Based on data from paired somatic/germline testing programs, other genes with a significant $(>20 \%)$ chance of testing positive in the germline when seen in somatic tissue include the Lynch genes ( $M L H 1, M S H 2$, MSH6, PMS2, and EPCAM) and PALB2 (Meric-Bernstam et al. 2016). A reasonable argument could be made to proceed with germline testing that includes pathogenic or likely pathogenic somatic variants in any of these genes, but there is limited infor- 


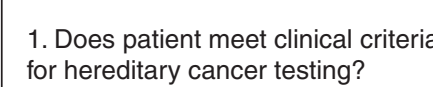
2. Does somatic report show TMB or
MSI-H tumor?

\section{Have germline results been filtered out of somatic report?}

\section{Are there any known founder} mutations in the somatic report?

5. Are any somatic variants classified as $P / L P^{*}$ in the germline?

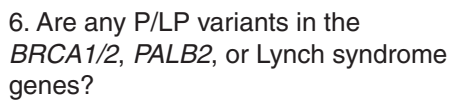

7. Are any $P / L P$ variants particularly common in somatic tissue (e.g., TP53, APC)

\section{Proceed with germline testing based on clinical criteria.}

Proceed with germline testing that includes Lynch syndrome and POLE/POLD1 genes.

Yes $\quad$ No further testing unless other clinical criteria are met.

Proceed with germline testing that includes the founder mutation.

No further testing for B/LB/VUS* variants unless other clinical criteria are met.

Proceed with germline testing that includes the P/LP variant.

Proceed with germline testing for common somatic variants only if there is some clinical indication (e.g., polyposis and APC mutations).

8. Further decisions about testing for rare or moderate penetrance variants should be based on clinical judgement and potential clinical implications for the patient and family members.

${ }^{*} \mathrm{~B}=$ Benign, LB = Likely Benign, VUS = Variant of Uncertain Significance, LP = Likely Pathogenic, $\mathrm{P}=$ Pathogenic.

Figure 1. Flowchart to assess somatic results for potential germline testing.

mation regarding incidence of moderate-risk genes, such as ATM, CHEK2, RAD51C, and others. The provider may wish to consider the potential clinical impact of a pathogenic variant for various genes (Table 4).

Step 7. Conversely, many genes common in tumor cells are only rarely confirmed in the germline. These include, but are not limited to, APC, TP53, MEN1, NF2, PTEN RET, STK11, and VHL (Meric-Bernstam et al.
2016). The syndromes associated with these genes tend to have distinctive phenotypes. Although clinical assessment is not always a perfect predictor of germline variants, given the low overall proportion of germline variants in these genes, it may be appropriate to proceed with testing of P/LP variants only when there are additional clinical indications. Sometimes, the nonquantifiable "clinical judgment" may come into play. 
A. Forman and J. Sotelo

Table 3. Resources to help assess somatic variants for germline testing

\begin{tabular}{|c|c|c|}
\hline \multirow[t]{4}{*}{ Transcript determination } & Ensembl genome browser & useast.ensembl.org/index.html \\
\hline & UCSC Genome Browser & www.genome.ucsc.edu \\
\hline & NCBI Genome & www.ncbi.nlm.nih.gov/genome \\
\hline & RefSeqGene & www.ncbi.nlm.nih.gov/refseq/rsg \\
\hline \multirow{5}{*}{$\begin{array}{c}\text { Somatic variant } \\
\text { classification }\end{array}$} & My Cancer Genome & www.mycancergenome.org \\
\hline & cBioPortal, Memorial Sloan Kettering & www.cbioportal.org \\
\hline & IARC TP53 mutation database & p53.iarc.fr \\
\hline & International Cancer Genome Consortium & www.icgc.org \\
\hline & Catalog of Somatic Mutations in Cancer (COSMIC) & cancer.sanger.ac.uk/cosmic \\
\hline \multirow{5}{*}{$\begin{array}{l}\text { Germline variant } \\
\text { classification }\end{array}$} & Clinvar & www.ncbi.nlm.nih.gov/clinvar \\
\hline & Clinvitae & clinvitae.invitae.com \\
\hline & $\begin{array}{l}\text { International Society for Gastrointestinal } \\
\text { Hereditary Tumors (InSiGHT) }\end{array}$ & www.insight-database.org \\
\hline & Human Gene Mutation Database (HGMD) & www.hgmd.cf.ac.uk/ac/index.php \\
\hline & Leiden Open Variant Database & www.lovd.nl \\
\hline \multirow[t]{2}{*}{ Gene tumor frequencies } & cBio Portal & www.cbioportal.org \\
\hline & COSMIC & cancer.sanger.ac.uk/cosmic \\
\hline \multirow{6}{*}{$\begin{array}{l}\text { Germline population } \\
\text { frequencies }\end{array}$} & ExAC & exac.broadinstitute.org/ \\
\hline & Genome Aggregation Database (gnomAD) & gnomad.broadinstitute.org/ \\
\hline & 1000 Genomes & browser.1000genomes.org \\
\hline & Exome variant server & evs.gs.washington.edu/EVS \\
\hline & $\mathrm{dbSNP}$ & www.ncbi.nlm.nih.gov/snp \\
\hline & dbVar & www.ncbi.nlm.nih.gov/dbvar \\
\hline \multirow[t]{4}{*}{ Gene association } & GeneReviews & $\begin{array}{l}\text { www.ncbi.nlm.nih.gov/books/ } \\
\text { NBK1116 }\end{array}$ \\
\hline & GeneCards & www.genecards.org \\
\hline & Genetics Home Reference & www.ghr.nlm.nih.gov \\
\hline & Online Medelian Inheritance in Man (OMIM) & www.omim.org \\
\hline
\end{tabular}

Step 8. Debatably, other genes should be considered for confirmatory germline testing. The ACMG has developed a list of 25 cancer genes (among others) representing highly penetrant genetic disorders in an attempt to reduce the morbidity and mortality associated with these genes (Kalia et al. 2017) and this list may serve as a baseline for some clinicians. Many of the publications examining results from paired somatic and germline testing to date have not included moderate-penetrance genes such as CHEK2 and ATM, yet pathogenic variants from these genes have the potential to affect cancer risk screening, given recommendations from NCCN and others (NCCN 1.2018; NCCN 3.2019). See Table 4.

As a final step, there will need to be a process developed to follow up with the ordering provider or the patient in order to ensure that co- ordination of germline testing is appropriately facilitated.

\section{Case 2}

A 54-year-old man was recently diagnosed with Stage IV gastric adenocarcinoma with signet ring cells, also known as diffuse gastric cancer (DGC). After progressing through several lines of therapy, he underwent testing with a commercial multiplatform, solid tumor biomarker analysis. The tumor was found to be Her2/ Neu-negative by IHC and MSI-stable. Two somatic variants were noted, a pathogenic variant in TP53 and a variant of uncertain significance in $C D H 1$. The patient was referred to a genetic counselor for consideration of germline genetic testing.

The genetic counselor involved with this case noted that $\sim 12 \%$ of gastric cancers will 
Table 4. Hereditary cancer risk genes and screening implications

\begin{tabular}{|c|c|c|c|c|c|}
\hline Hereditary cancer risk genes & $\mathrm{ACMG}^{\mathrm{a}}$ & $\begin{array}{l}\text { Screening } \\
\text { guidelines }\end{array}$ & $\begin{array}{c}\text { Hereditary } \\
\text { cancer risk genes }\end{array}$ & $\mathrm{ACMG}^{\mathrm{a}}$ & $\begin{array}{l}\text { Screening } \\
\text { guidelines }\end{array}$ \\
\hline$A P C$ & $\checkmark$ & NCCN- GI & NF1 & & NCCN- HBOC \\
\hline APC $11307 \mathrm{~K}$ & & NCCN-GI & NF2 & $\checkmark$ & Evans et al. 2005 \\
\hline ATM & & NCCN- HBOC & $\begin{array}{l}\text { NTHL1 (biallelic } \\
\text { only) }\end{array}$ & & NCCN- GI \\
\hline AXIN2 & & NCCN- GI & $P A L B 2$ & & NCCN- HBOC \\
\hline$B A P 1$ & & Rai et al. 2016 & POLD1 & & NCCN- GI \\
\hline$B A R D 1$ & & $\mathrm{~N} / \mathrm{a}$ & POLE & & NCCN- GI \\
\hline$B M P R 1 A$ & $\checkmark$ & NCCN- GI & PTEN & $\checkmark$ & NCCN- HBOC \\
\hline$B R C A 1$ & $\checkmark$ & NCCN- HBOC & RAD50 & & $\mathrm{N} / \mathrm{a}$ \\
\hline BRCA2 & $\checkmark$ & NCCN- HBOC & RAD51C & & NCCN- HBOC \\
\hline BRIP1 & & NCCN- HBOC & $R A D 51 D$ & & NCCN- HBOC \\
\hline $\mathrm{CDH} 1$ & & NCCN- HBOC & $R B 1$ & $\checkmark$ & Skalet et al. 2018 \\
\hline CDKN2A & & Rossi et al. 2019 & $R E T$ & $\checkmark$ & Kloos et al. 2009 \\
\hline$C H E K 2^{\mathrm{b}}$ & & NCCN- HBOC & SDHA & $\checkmark$ & Lenders et al. 2014 \\
\hline CTNNA1 & & $\mathrm{N} / \mathrm{a}$ & $S D H B$ & $\checkmark$ & \\
\hline DICER1 & & Schultz et al. 2018 & $S D H C$ & $\checkmark$ & \\
\hline GREM1 & & NCCN- GI & $S D H D$ & $\checkmark$ & \\
\hline HOXB13 & & Giri et al. 2018 & SMAD4 & $\checkmark$ & NCCN- GI \\
\hline MEN1 & $\checkmark$ & $\begin{array}{l}\text { Thakker et al. } \\
2012\end{array}$ & STK11 & $\checkmark$ & NCCN- HBOC \\
\hline $\begin{array}{l}\text { Lynch syndrome/MMR genes } \\
\qquad(M L H 1, M S H 2, M S H 6, P M S 2 \text {, } \\
\text { EPCAM) }\end{array}$ & $\checkmark$ & NCCN- GI & TP53 & $\checkmark$ & NCCN- HBOC \\
\hline MSH3 (biallelic only) & & NCCN- GI & TSC1 & $\checkmark$ & Krueger et al. 2013 \\
\hline MUTYH (monoallelic) & & NCCN- GI & TSC2 & $\checkmark$ & \\
\hline MUTYH (biallelic) & $\checkmark$ & NCCN- GI & $V H L$ & $\checkmark$ & Poulsen et al. 2010 \\
\hline$N B N$ & & NCCN- HBOC & WT1 & $\checkmark$ & Lee et al. 2016 \\
\hline
\end{tabular}

have somatic variants in $C D H 1$, and there is limited data as to the proportion of somatic variants that are later confirmed in the germline. The reported somatic variant, c.D257Y, was classified as a variant of uncertain significance in the germline. In hereditary diffuse gastric cancer (HDGC) syndrome the average age of onset of DGC is $38 \mathrm{yr}$ (range: 14-69 yr) and testing is recommended for anyone diagnosed at age 40 or younger. When diagnosed at older ages, additional family history of gastric cancer or lobular breast cancer is part of testing criteria (van der Post et al. 2015). Although the patient did not have known breast or gastric cancer in his family, there was some question about his father having esophageal versus gastric cancer. Whereas the counselor and patient discussed the low likelihood of finding an actionable variant, the patient was interested in pursuing testing and willing to pay out-of-pocket costs, as he did not meet clinical criteria for testing. One potential benefit of testing would be to have the VUS status confirmed by a clinical laboratory, which would allow for future reclassification updates. Testing was pursued through a multigene cancer panel from a commercial laboratory.

Germline results showed a new pathogenic variant in $C D H 1$, called deletion exons 14-16, which had not been previously identified in the somatic test report. This new variant was noted 
to involve a large deletion that may not have been detectible through the somatic testing laboratory processes. The discovery of this germline variant has allowed for cascade testing of several family members.

This case illustrates the limitations of somatic genetic testing in regards to certain types of variants and also highlights some of the remaining challenges when determining which somatic tumor findings justify follow-up germline testing.

\section{DISCUSSION}

Although this review speaks to the current state of practice, many new changes are on the horizon. It is likely that most somatic analysis will become paired with germline analysis, and the ambiguity surrounding whether a somatic gene change is also present in the germline will no longer exist. These changes will hopefully lead to higher rates of insurance coverage for comprehensive germline analysis in cancer patients, likely extending testing to cancer patients that do not fit current guidelines for analysis. Additionally, somatic analysis has already led to increased understanding of how genes typically classified as "cardiac" or "general genetics" may contribute to cancer risk (i.e., NOTCH1, Rasopathies, RECQL1). The continued identification of crossover risks may lead to greater fluidity between the traditionally siloed specialties within genetics.

Significant limitations exist at this time to this summary of the science. Although it is known that methylation, structural variants, and variation in the introns and promoters are likely involved in tumorigenesis, comprehensive analysis of these areas and types of genomic variation is uncommon, and we do not understand the implication of these alterations. Certainly, as our understanding of these variations deepens, the extent to which we acknowledge the interplay between somatic and germline variants will also broaden. The current data regarding somatic testing is limited by the reliance on sequencing and deletion and duplication of the DNA strand only.
As somatic technologies have primarily been performed in countries of European descent and among well-insured individuals in the United States, there is a significant lack of data about tumor profiles in individuals from non-White and Hispanic racial and ethnic groups. Until genomic research, both germline and somatic, is intentionally designed to capture genomic data from individuals that represent the global population, its applicability to understanding and treating cancer is hampered. There are likely many genetic nuances in each population that affect prognosis, response, baseline risk, and recurrence risk, and the current extrapolation of existing research to populations not included in the source data is limiting.

Further research will be needed to understand how other genomic changes in the germline (methylation, variable expression) effect tumorigenesis, how the tumorigenesis process may differ in racial and ethnic communities outside of European ancestry and how best, or if at all, to silo identified variants into areas of specialty.

\section{REFERENCES}

Alexandrov LB, Nik-Zainal S, Wedge DG, Aparicio SA, Behjati S, Biankin AV, Bignell AG, Bolli N, Borg A, BørresenDale AL, et al. 2013. Signatures of mutational processes in human cancer. Nature 500: 415-421. doi:10.1038/na ture 12477

Bailey MH, Tokheim C, Porta-Pardo E, Sengupta S, Betrand D, Weerasinghe A, Colaprico A, Wendi MC, Kim J, Reardon B, et al. 2018. Comprehensive characterization of cancer driver genes and mutations. Cell 173: 371-385. e18. doi:10.1016/j.cell.2018.02.060

Barbany G, Arthur C, Leiden A, Nordenskjold M, Rosenquist R, Tesi B, Wallander K, Tham E. 2019. Cell free tumour DNA testing for early detection of cancer-a potential future tool. J Int Med 286: 118-136. doi:10.1111/ joim. 12897

Barrera LO, Li Z, Smith AD, Arden KC, Cavenee WK, Zhang MQ, Green RD, Ren B. 2008. Genome-wide mapping and analysis of active promoters in mouse embryonic stem cells and adult organs. Genome Res 18: 46-59. doi:10 $.1101 /$ gr.6654808

Bentley DR, Balasubramanian S, Swerdlow HP, Smith GP, Milton J, Brown CG, Hall KP, Evers DJ, Barnes CL, Bignell HR, et al. 2008. Accurate whole human genome sequencing using reversible terminator chemistry. Nature 456: $53-59$. doi:10.1038/nature 07517

Boland CR, Thibodeau SN, Hamilton SR, Sidransky D, Eshleman JR, Burt RW, Meltzer SJ, Rodriguez-Bigas MA, Fodde 
R, Ranzani GN, et al. 1998. A National Cancer Institute Workshop on Microsatellite Instability for cancer detection and familial predisposition: development of international criteria for the determination of microsatellite instability in colorectal cancer. Cancer Res 58: 5248-5257.

Boland CR, Koi M, Chang DK, Carethers JM. 2008. The biochemical basis of microsatellite instability and abnormal immunohistochemistry and clinical behavior in Lynch syndrome: from bench to bedside. Fam Cancer 7: 41-52. doi:10.1007/s10689-007-9145-9

Cheng DT, Mitchell TN, Zehir A, Shah RH, Benayed R, Syed A, Chandramohan R, Liu ZY, Won HH, Scott SN, et al. 2015. Memorial Sloan Kettering-Integrated Mutation Profiling of Actionable Cancer Targets (MSK-IMPACT): a hybridization capture-based next-generation sequencing clinical assay for solid tumor molecular oncology. $J$ Mol Diagn 17: 251-264. doi:10.1016/j.jmoldx.2014.12 .006

Cheng DT, Prasad M, Chekaluk Y, Benayed R, Sadowska J, Zehir A, Syed A, Wang YE, Somar J, Li Y, et al. 2017. Comprehensive detection of germline variants by MSKIMPACT, a clinical diagnostic platform for solid tumor molecular oncology and concurrent cancer predisposition testing. BMC Med Genomics 10: 33. doi:10.1186/ s12920-017-0271-4

Cortes-Ciriano I, Lee S, Park WY, Kim TM, Park PJ. 2017. A molecular portrait of microsatellite instability across multiple cancers. Nat Commun 8: 15180. doi:10.1038/ ncomms 15180

Dalgleish R, Flicek P, Cunningham F, Astashyn A, Tully RE, Proctor G, Chen Y, McLaren WM, Larsson P, Vaughan BW, et al. 2010. Locus reference genomic sequences: an improved basis for describing human DNA variants. Genome Med 2: 24. doi:10.1186/gm145

de la Chapelle A, Hampel H. 2010. Clinical relevance of microsatellite instability in colorectal cancer. J Clin Oncol 28: 3380-3387. doi:10.1200/JCO.2009.27.0652

Dick JE. 2008. Stem cell concepts renew cancer research. Blood 112: 4793-4807. doi:10.1182/blood-2008-08077941

Domchek SM. 2017. Reversion mutations with clinical use of PARP inhibitors: many genes, many versions. Cancer Discov 7: 937-939. doi:10.1158/2159-8290.CD-17-0734

Evaluation of Genomic Applications in Practice and Prevention (EGAPP) Working Group. 2009. Recommendations from the EGAPP Working Group: genetic testing strategies in newly diagnosed individuals with colorectal cancer aimed at reducing morbidity and mortality from Lynch syndrome in relatives. Genet Med 11:35-41. doi:10.1097/ GIM.0b013e31818fa2ff

Evans DG, Baser ME, O'Reilly B, Rowe J, Gleeson M, Saeed S, King A, Huson SM, Kerr R, Thomas N, et al. 2005. Management of the patient and family with neurofibromatosis 2: a consensus conference statement. Br J Neurosurg 19: 5-12. doi:10.1080/02688690500081206

Fidler IJ, Hart IR. 1982. Biological diversity in metastatic neoplasms: origins and implications. Science 217: 998 1003. doi:10.1126/science. 7112116

Frick M, Chan W, Arends CM, Hablesreiter R, Halik A, Heuser M, Michonneau D, Blau O, Hoyer K, Christen F, et al. 2019. Role of donor clonal hematopoiesis in allo- geneic hematopoietic stem-cell transplantation. $J$ Clin Oncol 37: 375-385. doi:10.1200/JCO.2018.79.2184

Giri VN, Knudsen KE, Kelly WK, Abida W, Andriole GL, Bangma CH, Bekelman JE, Benson MC, Blanco A, Burnet A, et al. 2018. Role of genetic testing for inherited prostate cancer risk: Philadelphia Prostate Cancer Consensus Conference 2017. J Clin Oncol 36: 414-424. doi:10 $.1200 / J C O .2017 .74 .1173$

Goldstein JB, Wu W, Borras E, Masand G, Cuddy A, Mork ME, Bannon SA, Lynch PM, Rodriguez-Bigas M, Taggart MW, et al. 2017. Can microsatellite status of colorectal cancer be reliably assessed after neoadjuvant therapy? Clin Cancer Res 23: 5246-5254. doi:10.1158/1078-0432 .CCR-16-2994

Gondek LP, Zheng G, Ghiaur G, DeZern AE, Matsui W, Yegnasubramanian S, Lin MT, Levis M, Eshleman JR, Varadhan R, et al. 2016. Donor cell leukemia arising from clonal hematopoiesis after bone marrow transplantation. Leukemia 30: 1916-1920. doi:10.1038/leu.2016.63

Gupta R, Wikramasinghe P, Bhattacharyya A, Perez FA, Pal S, Davuluri RV. 2010. Annotation of gene promoters by integrative data-mining of ChIP-seq Pol-II enrichment data. BMC Bioinformatics 11: S65. doi:10.1186/14712105-11-S1-S65

Hampel H. 2016. Genetic counseling and cascade genetic testing in Lynch syndrome. Fam Cancer 15: 423-427. doi:10.1007/s10689-016-9893-5

Hampel H, Frankel W, Panescu J, Lockman J, Sotamaa K, Fix D, Comeras I, La Jeunesse J, Nakagawa H, Westman JA, et al. 2006. Screening for Lynch syndrome (hereditary nonpolyposis colorectal cancer) among endometrial cancer patients. Cancer Res 66: 7810-7817. doi:10.1158/00085472.CAN-06-1114

Hampel H, Frankel WL, Martin E, Arnold M, Khanduja K, Kuebler P, Clendenning M, Sotamaa K, Prior T, Westman JA, et al. 2008. Feasibility of screening for Lynch syndrome among patients with colorectal cancer. J Clin Oncol 26: 5783-5788. doi:10.1200/JCO.2008.17.5950

Hampel H, Pearlman R, Beightol M, Zhao W, Jones D, Frankel WL, Goodfellow PJ, Yilmaz A, Miller K, Bacher J, et al. 2018. Assessment of tumor sequencing as a replacement for Lynch syndrome screening and current molecular tests for patients with colorectal cancer. JAMA Oncol 4: 806-813. doi:10.1001/jamaoncol.2018 .0104

Hellwig S, Nix DA, Gligorich KM, O'Shea JM, Thomas A, Fuertes CL, Bhetariya PJ, Marth GT, Bronner MP, Underhill HR. 2018. Automated size selection for short cell-free DNA fragments enriches for circulating tumor DNA and improves error correction during next generation sequencing. PLoS ONE 13: e0197333. doi:10.1371/journal .pone. 0197333

Heppner GH. 1984. Tumor heterogeneity. Cancer Res 44: 2259-2265.

Hiemcke-Jiwa LS, ten Dam-van Loon NH, Leguit RJ, Nierkens S, Ossewaarde-van Norel J, de Boer JH, Roholl FF, de Weger RA, Huibers MMH, de Groot-Mijnes JDF, et al. 2018. Potential diagnosis of vitreoretinal lymphoma by detection of MYD88 mutation in aqueous humor with ultrasensitive droplet digital polymerase chain reaction. JAMA Ophthalmol 136: 1098-1104. doi:10.1001/ja maophthalmol.2018.2887 
Huang X, Tse JY, Protopopov A, Russell M, Weeraratne D, Ring JE, Bjonnes A, Pei S, Sun R, Lvova M, et al. 2018. Characterization of tumor mutation burden (TMB) and microsatellite instability (MSI) interplay for gastroesophageal adenocarcinoma (GA) and colorectal carcinoma (CRC). J Clin Oncol 36: 22. doi:10.1200/JCO.2018.36 .5_suppl.22

Jahr S, Hentze H, Englisch S, Hardt D, Fackelmayer FO, Hesch RD, Knippers R. 2001. DNA fragments in the blood plasma of cancer patients: quantitations and evidence for their origin from apoptotic and necrotic cells. Cancer Res 61: 1659-1665.

Jain R, Savage MJ, Forman AD, Mukherji R, Hall MJ. 2016. The relevance of hereditary cancer risks to precision oncology: what should providers consider when conducting tumor genomic profiling? J Natl Compr Canc Netw 14: 795-806.

Jaiswal S, Fontanillas P, Flannick J, Manning A, Grauman PV, Mar BG, Lindsley RC, Mermel CH, Burtt N, Chavez A, et al. 2014. Age-related clonal hematopoiesis associated with adverse outcomes. N Engl J Med 371: 2488-2498. doi:10.1056/NEJMoa1408617

Jaiswal S, Natarajan P, Silver AJ, Gibson CJ, Bick AG, Shvartz E, McConkey M, Gupta N, Gabriel S, Ardissino D, et al. 2017. Clonal hematopoiesis and risk of atherosclerotic cardiovascular disease. $N$ Engl J Med 377: 111-121. doi:10.1056/NEJMoa1701719

Jiang P, Chan CW, Chan KC, Cheng SH, Wong J, Wong VW, Wong GL, Chan SL, Mok TS, Chan HL, et al. 2015. Lengthening and shortening of plasma DNA in hepatocellular carcinoma patients. Proc Natl Acad Sci 112: E1317-E1325. doi:10.1073/pnas.1500076112

Kalia SS, Adelman K, Bale SJ, Chung WK, Eng C, Evans JP, Herman GE, Hufnagel SB, Klein TE, Korf BR, et al. 2017. Recommendations for reporting of secondary findings in clinical exome and genome sequencing, 2016 update (ACMG SF v2.0): a policy statement of the American College of Medical Genetics and Genomics. Genet Med 19: 249-255. doi:10.1038/gim.2016.190

Kanchi KL, Johnson KJ, Lu C, McLellan MD, Leiserson MD, Wendl MC, Zhang Q, Koboldt DC, Xie M, Kandoth C, et al. 2014. Integrated analysis of germline and somatic variants in ovarian cancer. Nat Commun 5: 3156. doi:10 $.1038 /$ ncomms4156

Karczewski KJ, Francioli LC, Tiao G, Collins RL, Cummings BB, Alföldi J, Wang Q, Laricchia KM, Kosmicki JA, Ganna A, et al. 2019. Variation across 141,456 human exomes and genomes reveals the spectrum of loss-offunction intolerance across human protein-coding genes. Cold Spring Harbor Laboratory: ASHG Platform Session. bioRxiv doi:10.1101/531210

Kent WJ, Sugnet CW, Furey TS, Roskin KM, Pringle TH, Zahler AM, Haussler D. 2002. The human genome browser at UCSC. Genome Res 12: 996-1006. doi:10 $.1101 /$ gr.229102

Kim TM, Laird PW, Park PJ. 2013. The landscape of microsatellite instability in colorectal and endometrial cancer genomes. Cell 155: 858-868. doi:10.1016/j.cell.2013.10 .015

Kloos RT, Eng C, Evans DB, Francis GL, Gagel RF, Gharib H, Moley JF, Pacini F, Ringel MD, Schlumberger M, et al. 2009. Medullary thyroid cancer: management guidelines of the American Thyroid Association. Thyroid 19: 565612. doi:10.1089/thy.2008.0403

Knijnenburg TA, Wang L, Zimmermann MT, Chambwe N, Gao GF, Cherniack AD, Fan H, Shen H, Way GP, Greene CS, et al. 2018. Genomic and molecular landscape of DNA damage repair deficiency across the Cancer Genome Atlas. Cell Rep 23: 239-254.e6. doi:10.1016/j .celrep.2018.03.076

Krammer J, Pinker-Domenig K, Robson ME, Gönen M, Bernard-Davila B, Morris EA, Mangino DA, Jochelson MS. 2017. Breast cancer detection and tumor characteristics in BRCA1 and BRCA2 mutation carriers. Breast Cancer Res Treat 163: 565-571. doi:10.1007/s10549017-4198-4

Krueger DA, Northrup H; International Tuberous Sclerosis Complex Consensus Group. 2013. Tuberous sclerosis complex surveillance and management: recommendations of the 2012 International Tuberous Sclerosis Complex Consensus Conference. Pediatr Neurol 49: 255-265. doi:10.1016/j.pediatrneurol.2013.08.002

Landrum MJ, Lee JM, Benson M, Brown GR, Chao C, Chitipiralla S, Gu B, Hart J, Hoffman D, Jang W, et al. 2018 ClinVar: improving access to variant interpretations and supporting evidence. Nucleic Acids Res 46: D1062D1067. doi:10.1093/nar/gkx1153

Le DT, Uram JN, Wang H, Bartlett BR, Kemberling H, Eyring $\mathrm{AD}$, Skora AD, Luber BS, Azad NS, Laheru D, et al 2015. PD-1 blockade in tumors with mismatch-repair deficiency. N Engl J Med 372: 2509-2520. doi:10.1056/ NEJMoa1500596

Lee PA, Nordenström A, Houk CP, Ahmed SF, Auchus R, Baratz A, Baratz Dalke K, Liao LM, Lin-Su K, Looijenga L III, et al. 2016. Global disorders of sex development update since 2006: perceptions, approach and care. Horm Res Paediatr 85: 158-180. doi:10.1159/000442975

Lek M, Karczewski K, Minikel E, Samocha K, Banks E, Fennell T, O'Donnell-Luria AH, Ware J, Hill A, Cummings BB. 2016. Analysis of protein-coding genetic variation in 60,706 humans. Nature 536: 285-291. doi:10.1038/na ture19057

Lenders JW, Duh Q, Eisenhofer G, Gimenez-Roqueplo A, Grebe SK, Murad SM, Naruse M, Pacak K, Young WF. 2014. Pheochromocytoma and paraganglioma: an Endocrine Society Clinical Practice Guideline. J Clin Endocrinol Metab 99: 1915-1942. doi:10.1210/jc.2014-1498

Leon SA, Shapiro B, Sklaroff DM, Yaros MJ. 1977. Free DNA in the serum of cancer patients and the effect of therapy. Cancer Res 37: 646-650.

Li M, Stoneking M. 2012. A new approach for detecting lowlevel mutations in next-generation sequence data. Genome Biol 13: R34. doi:10.1186/gb-2012-13-5-r34

Li M, Datto M, Duncavage EJ, Kulkarni S, Lindeman NI, Roy S, Tsimberidou AM, Vnencak-Jones CL, Wolff DJ, Younes A, et al. 2017. Standards and guidelines for the interpretation and reporting of sequence variants in cancer: A Joint Consensus Recommendation of the Association for Molecular Pathology, American Society of Clinical Oncology, and College of American Pathologists. J Mol Diagn 19: 4-23. doi:10.1016/j.jmoldx.2016.10.002

Lin MT, Mosier SL, Thiess M, Beierl KF, Debeljak M, Tseng LH, Chen G, Yegnasubramanian S, Ho H, Cope L, et al. 2014. Clinical validation of KRAS, BRAF, and EGFR mu- 
tation detection using next-generation sequencing. $A m \mathrm{~J}$ Clin Pathol 141: 856-866. doi:10.1309/AJCPMWGW GO34EGOD

Luthra R, Patel KP, Reddy NG, Haghshenas V, Routbort MJ, Harmon MA, Barkoh BA, Kanagal-Shamanna R, Ravandi F, Cortes JE, et al. 2014. Next-generation sequencingbased multigene mutational screening for acute myeloid leukemia using MiSeq: applicability for diagnostics and disease monitoring. Haematologica 99: 465-473. doi:10 .3324/haematol.2013.093765

Mandelker D, Zhang L. 2018. The emerging significance of secondary germline testing in cancer genomics. J Pathol 244: 610-615. doi:10.1002/path.5031

Mayor P, Gay LM, Lele S, Elvin JA. 2017. BRCA1 reversion mutation acquired after treatment identified by liquid biopsy. Gynecol Oncol Rep 21: 57-60. doi:10.1016/j.gore 2017.06.010

McLaren W, Gil L, Hunt SE, Riat HS, Ritchie GR, Thormann A, Flicek P, Cunningham F. 2016. The Ensembl variant effect predictor. Genome Biol 17: 122. doi:10.1186/ s13059-016-0974-4

Meric-Bernstam F, Brusco L, Daniels M, Wathoo C, Bailey AM, Strong L, Shaw K, Lu K, Qi Y, Zhao H, et al. 2016. Incidental germline variants in 1000 advanced cancers on a prospective somatic genomic profiling protocol. Ann Oncol 27: 795-800. doi:10.1093/annonc/mdw018

National Comprehensive Cancer Network (NCCN). NCCN Clinical Practice Guidelines in Oncology. Genetic/ Familial High-Risk Assessment: Colorectal Version 1.2018. July 12, 2018. Available at https://www.nccn.org/ professionals/physician_gls/pdf/genetics_colon.pdf.

National Comprehensive Cancer Network (NCCN). NCCN Clinical Practice Guidelines in Oncology. Genetic/Familial High-Risk Assessment: Breast and Ovarian. Version 3.2019. January 18, 2019. Available at https://www.ncen .org/professionals/physician_gls/pdf/genetics_screening .pdf.

Nicolson GL. 1984. Generation of phenotypic diversity and progression in metastatic tumor cells. Cancer Metastasis Rev 3: 25-42. doi:10.1007/BF00047691

Nikiforova MN, Wald AI, Roy S, Durso MB, Nikiforov YE. 2013. Targeted next-generation sequencing panel (ThyroSeq) for detection of mutations in thyroid cancer. J Clin Endocrinol Metab 98: E1852-E1860. doi:10.1210/jc .2013-2292

Peng YC, Chen YB. 2018. Recognizing hereditary renal cancers through the microscope: a pathology update. Surg Pathol Clin 11: 725-737. doi:10.1016/j.path.2018.07.010

Peshkin BN, Alabek ML, Isaacs C. 2010. BRCA1/2 mutations and triple negative breast cancers. Breast Dis 32: 25-33. doi:10.3233/BD-2010-0306

Poulsen ML, Budtz-Jørgensen E, Bisgaard ML. 2010. Surveillance in von Hippel-Lindau disease (vHL). Clin Genet 77: 49-59. doi:10.1111/j.1399-0004.2009.01281.x

Rai K, Pilarski R, Cebulla CM, Abdel-Rahman MH. 2016. Comprehensive review of BAP1 tumor predisposition syndrome with report of two new cases. Clin Genet 89: 285-294. doi:10.1111/cge.12630

Raymond VM, Gray SW, Roychowdhury S, Joffe S, Chinnaiyan AM, Parsons DW, Plon SE. 2016. Germline findings in tumor-only sequencing: points to consider for clinicians and laboratories. J Natl Cancer Inst 108: djv351. doi:10.1093/jnci/djv351

Richards S, Aziz N, Bale S, Bick D, Das S, Gastier-Foster J, Grody WW, Hegde M, Lyon E, Spector E, et al. 2015. Standards and guidelines for the interpretation of sequence variants: a joint consensus recommendation of the American College of Medical Genetics and Genomics and the Association for Molecular Pathology. Genet Med 17: 405-424. doi:10.1038/gim.2015.30

Rohlin A, Wernersson J, Engwall Y, Wiklund L, Björk J, Nordling M. 2009. Parallel sequencing used in detection of mosaic mutations: comparison with four diagnostic DNA screening techniques. Hum Mutat 30: 1012-1020. doi:10.1002/humu.20980

Rossi M, Pellegrini C, Cardelli L, Ciciarelli V, Di Nardo L, Fargnoli MC. 2019. Familial melanoma: diagnostic and management implications. Dermatol Pract Concept 9: 1016. doi:10.5826/dpc.0901a03

Rykova EY, Morozkin ES, Ponomaryova AA, Loseva EM, Zaporozhchenko IA, Cherdyntseva NV, Vlassov VV, Laktionov PP. 2012. Cell-free and cell-bound circulating nucleic acid complexes: mechanisms of generation, concentration and content. Expert Opin Biol Ther 12: S141153. doi:10.1517/14712598.2012.673577

Salipante SJ, Scroggins SM, Hampel HL, Turner EH, Pritchard CC. 2014. Microsatellite instability detection by next generation sequencing. Clin Chem 60: 1192-1199. doi:10 .1373/clinchem.2014.223677

Salvador MU, Truelson MRF, Mason C, Souders B, LaDuca H, Dougall B, Black MH, Fulk K, Profato J, Gutierrez S, et al. 2019. Comprehensive paired tumor/germline testing for Lynch syndrome: bringing resolution to the diagnostic process. J Clin Oncol 37: 647-657. doi:10.1200/JCO.18 .00696

Schrader KA, Cheng DT, Joseph V, Prasad M, Walsh M, Zehir A, Ni A, Thomas T, Benayed R, Ashraf A, et al. 2016. Germline variants in targeted tumor sequencing using matched normal DNA. JAMA Oncol 2: 104-111. doi:10.1001/jamaoncol.2015.5208

Schultz KP, Williams GM, Kamihara J, Stewart DR, Harris AK, Bauer AJ, Turner J, Shah R, Schneider K, Schneider $\mathrm{KW}$, et al. 2018. DICER1 and associated conditions: identification of at-risk individuals and recommended surveillance strategies. Clin Cancer Res 24: 2251-2261. doi:10 .1158/1078-0432.CCR-17-3089

Schwarzenbach H, Müller V, Milde-Langosch K, Steinbach B, Pantel K. 2011. Evaluation of cell-free tumour DNA and RNA in patients with breast cancer and benign breast disease. Mol Biosyst 7: 2848-2854. doi:10.1039/clmb 05197k

Shendure J, Ji H. 2008. Next-generation DNA sequencing. Nat Biotechnol 26: 1135-1145. doi:10.1038/nbt1486

Singer GA, Wu J, Yan P, Plass C, Huang TH, Davuluri RV 2008. Genome-wide analysis of alternative promoters of human genes using a custom promoter tiling array. $B M C$ Genomics 9: 349. doi:10.1186/1471-2164-9-349

Singh RR, Patel KP, Routbort MJ, Reddy NG, Barkoh BA, Handal B, Kanagal-Shamanna R, Greaves WO, Medeiros LJ, Aldape KD, et al. 2013. Clinical validation of a nextgeneration sequencing screen for mutational hotspots in 46 cancer-related genes. J Mol Diagn 15: 607-622. doi:10 .1016/j.jmoldx.2013.05.003 
A. Forman and J. Sotelo

Skalet AH, Gombos DSM, Gallie BL, Kim JW, Shields CL Marr BP, Plon SE, Chévez-Barrios P. 2018. Screening children at risk for retinoblastoma: consensus report from the American Association of Ophthalmic Oncologists and Pathologists. Ophthalmology 125: 453-458. doi:10.1016/j.ophtha.2017.09.001

Sperling AS, Gibson CJ, Ebert BL. 2017. The genetics of myelodysplastic syndrome: from clonal haematopoiesis to secondary leukaemia. Nat Rev Cancer 17: 5-19. doi:10.1038/nrc.2016.112

Steensma DP. 2018. Clinical consequences of clonal hematopoiesis of indeterminate potential. Blood Adv 2: 34043410. doi:10.1182/bloodadvances.2018020222

Steensma DP, Bejar R, Jaiswal S, Lindsley RC, Sekeres MA, Hasserjian RP, Ebert BL. 2015. Clonal hematopoiesis of indeterminate potential and its distinction from myelodysplastic syndromes. Blood 126: 9-16. doi:10.1182/ blood-2015-03-631747

Stroun M, Anker P, Lyautey J, Lederrey C, Maurice PA. 1987. Isolation and characterization of DNA from the plasma of cancer patients. Eur J Cancer Clin Oncol 23: 707-712. doi:10.1016/0277-5379(87)90266-5

Sun JX, He Y, Sanford E, Montesion M, Frampton GM, Vignot S, Soria JC, Ross JS, Miller VA, Stephens PJ, et al. 2018. A computational approach to distinguish somatic vs. germline origin of genomic alterations from deep sequencing of cancer specimens without a matched normal. PLoS Comput Biol 14: e1005965.

Syngal S, Fox EA, Eng C, Kolodner RD, Garber JE. 2000. Sensitivity and specificity of clinical criteria for hereditary non-polyposis colorectal cancer associated mutations in MSH2 and MLH1. J Med Genet 37: 641-645. doi:10.1136/ jmg.37.9.641

Thakker RV, Newey PJ, Walls GV, Bilezikian J, Dralle H, Ebeling PR, Melmed S, Sakurai A, Tonelli F, Brandi ML. 2012. Clinical practice guidelines for multiple endocrine neoplasia type 1 (MEN1). J Clin Endocrinol Metab 97: 2990-3011. doi:10.1210/jc.2012-1230

Thierry AR, El Messaoudi S, Gahan PB, Anker P, Stroun M. 2016. Origins, structures, and functions of circulating DNA in oncology. Cancer Metastasis Rev 35: 347-376. doi:10.1007/s10555-016-9629-x

Tsongalis GJ, Peterson JD, de Abreu FB, Tunkey CD, Gallagher TL, Strausbaugh LD, Wells WA, Amos CI. 2014 Routine use of the Ion Torrent AmpliSeq ${ }^{\mathrm{TM}}$ Cancer Hot- spot Panel for identification of clinically actionable somatic mutations. Clin Chem Lab Med 52: 707-714. doi:10.1515/cclm-2013-0883

Underhill HR, Kitzman JO, Hellwig S, Welker NC, Daza R, Baker DN, Gligorich KM, Rostomily RC, Bronner MP, Shendure J. 2016. Fragment length of circulating tumor DNA. PLoS Genet 12: e1006162. doi:10.1371/journal .pgen.1006162

van der Post RS, Vogelaar IP, Carneiro F, Guilford P, Huntsman D, Hoogerbrugge N, Caldas C, Schreiber KE, Hardwick RH, Ausems MG, et al. 2015. Hereditary diffuse gastric cancer: updated clinical guidelines with an emphasis on germline $\mathrm{CDH} 1$ mutation carriers. J Med Genet 52: 361-374. doi:10.1136/jmedgenet-2015-103094

Wan JCM, Massie C, Garcia-Corbacho J, Mouliere F, Brenton JD, Caldas C, Pacey S, Baird R, Rosenfeld N. 2017. Liquid biopsies come of age: towards implementation of circulating tumour DNA. Nat Rev Cancer 17: 223-238. doi:10.1038/nrc.2017.7

Wang ET, Sandberg R, Luo S, Khrebtukova I, Zhang L, Mayr C, Kingsmore SF, Schroth GP, Burge CB. 2008. Alternative isoform regulation in human tissue transcriptomes. Nature 456: 470-476. doi:10.1038/nature07509

Weigelt B, Comino-Méndez I, de Bruijn I, Tian L, Meisel JL, García-Murillas I, Fribbens C, Cutts R, Martelotto LG, Ng CKY, et al. 2017. Diverse BRCA1 and BRCA2 reversion mutations in circulating cell-free DNA of therapy-resistant breast or ovarian cancer. Clin Cancer Res 23: 67086720. doi:10.1158/1078-0432.CCR-17-0544

Zehir A, Benayed R, Shah RH, Syed A, Middha S, Kim HR, Srinivasan P, Gao J, Chakravarty D, Devlin SM, et al. 2017. Mutational landscape of metastatic cancer revealed from prospective clinical sequencing of 10,000 patients. Nat Med 23: 703-713. doi:10.1038/nm.4333

Zerbino DR, Achuthan P, Akanni W, Amode MR, Barrell D, Bhai J, Billis K, Cummins C, Gall A, Girón CG, et al. 2018. Ensembl 2018. Nucleic Acids Res 46: D754-D761. doi:10 $.1093 /$ nar/gkx1098

Zill OA, Banks KC, Fairclough SR, Mortimer SA, Vowles JV, Mokhtari R, Gandara DR, Mack PC, Odegaard JI, Nagy RJ, et al. 2018. The landscape of actionable genomic alterations in cell-free circulating tumor DNA from 21,807 advanced cancer patients. Clin Cancer Res 24: 3528-3538. doi:10.1158/1078-0432.CCR-17-3837 


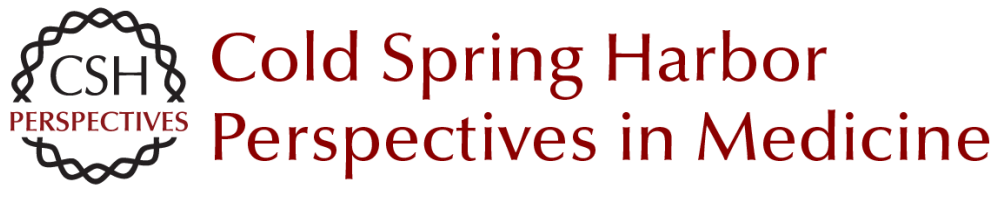

\section{Tumor-Based Genetic Testing and Familial Cancer Risk}

Andrea Forman and Jilliane Sotelo

Cold Spring Harb Perspect Med 2020; doi: 10.1101/cshperspect.a036590 originally published online September 30, 2019

\section{Subject Collection Genetic Counseling: Clinical Practice and Ethical Considerations}

Genetic Risk Assessment in Psychiatry Holly Landrum Peay

Birds of a Feather? Genetic Counseling, Genetic Testing, and Humanism Robert Resta

Bridging the Gap between Scientific Advancement and Real-World Application: Pediatric Genetic Counseling for Common Syndromes and Single-Gene Disorders Julie A. McGlynn and Elinor Langfelder-Schwind

Genetic Counseling, Personalized Medicine, and Precision Health Erica Ramos

Tumor-Based Genetic Testing and Familial Cancer Risk Andrea Forman and Jilliane Sotelo

A Person-Centered Approach to Cardiovascular Genetic Testing Julia Platt

Evidence-Based Genetic Counseling for Psychiatric Disorders: A Road Map Jehannine C. Austin

Supporting Patient Autonomy and Informed Decision-Making in Prenatal Genetic Testing Katie Stoll and Judith Jackson
Impact of Emerging Technologies in Prenatal

Genetic Counseling

Blair Stevens

Genetic Counseling and Assisted Reproductive

Technologies Debra Lilienthal and Michelle Cahr

Evolving Roles of Genetic Counselors in the Clinical Laboratory Megan T. Cho and Carrie Guy

Psychological Issues in Managing Families with Inherited Cardiovascular Diseases Jodie Ingles

Informed Consent in the Genomics Era Shannon Rego, Megan E. Grove, Mildred K. Cho, et al.

Predictive Genetic Counseling for

Neurodegenerative Diseases: Past, Present, and Future Jill S. Goldman

Cancer Genetic Counseling--Current Practice and Future Challenges Jaclyn Schienda and Jill Stopfer

Regulating Preimplantation Genetic Testing across the World: A Comparison of International Policy and Ethical Perspectives Margaret E.C. Ginoza and Rosario Isasi

For additional articles in this collection, see http://perspectivesinmedicine.cshlp.org/cgi/collection/ 